\title{
Determining the Views of Pre-School Children and Their Parents Regarding Museums: Safranbolu Case
}

\author{
Şehnaz Ceylan ${ }^{1, *} \&$ Nida Kılınç ${ }^{2}$ \\ ${ }^{1}$ Department of Child Development, School of Health, Karabuk University, Karabuk, Turkey \\ ${ }^{2}$ Yenice Nursery School, Yenice, Karabuk, Turkey \\ *Corresponding author: Yenice Nursery School, Yenice, Karabuk, Turkey. Tel: \\ 90-370-766-3066. E-mail: nida_kalkan@hotmail.com
}

Received: February 14, 2016 Accepted: March 10, 2016 Published: March 25, 2016

doi:10.5296/ije.v8i1.9208 URL: http://dx.doi.org/10.5296/ije.v8i1.9208

\begin{abstract}
The purpose of this study was to determine preschoolers' and their families' perceptions of the museum. Participant of the study included 20 children under the age of 5 studying in preschools and their families in 2014-2015 academic years. A semi-structured interview form developed by researchers based on the conceptual framework was used to gather data. Pre-test and posttest were conducted to determine preschoolers' perceptions of museum. The interview form was first examined via SPSS 15 Windows Packet and frequencies of families' perceptions of museum, percentage values and content analysis were conducted to analyze the data. Context analysis was used to find out the perceptions of children about museum. The results of the study shed light on preschoolers' perceptions of museum.
\end{abstract}

Keywords: Family, preschooler, perception of museum 


\section{Introduction}

Human beings start a social life from their birth. Children learn the attitudes, beliefs, codes of behaviors, and the behaviors expected from them within the society they live in (San-Bayhan and Artan, 2005). Early success achieved in early childhood will bring success in the upcoming years. Therefore, studies about early childhood have gained speed. Previous studies emphasize how important early childhood years are for early learning. In addition, it is reported that high motivation is influential on children's learning. Each individual in society should pay attention to providing children with environments of activity which support their early learning, motivate them, make them active, and they participate in with attention (Heckman, 2004).

As emphasized by Piaget in his theory, children behave based on their intuitions during the symbolic period covering the years between 4 and 7 . Therefore, the experiences they acquire through the events they undergo positively influence their development (Senemoğlu, 2007). Development is rapid in this period, and pre-school education institutions may help children to improve themselves by making them acquire some experiences which are appropriate for their ages and levels (Başal, 2005).

In this sense, the understanding of integrating differences into education has started to be handled along with many factors likely to have an effect on children's learning and teaching. It is possible to say that schools are no longer the only source of learning and information. Museums, exhibitions, and various similar learning environments may contribute to making the theoretical knowledge provided in schools permanent. This is an inevitable result of the advancements in technology which has developed rapidly in recent years and become part of people's daily lives at the same rate as well as the studies focusing on the learning skills of people within the same context. The idea of utilizing different learning methods and environments has started to settle in the center of education (Baykan, 2007; Önder, Abac1, Kamaraj, 2009).

The vital social functions of museums were mentioned in a study conducted by the Institute of Museum and Library Services (IMLS) (2013). According to that, museums are social service organizations that offer lifelong learning for the members of the society in which they exist and contribute to the cultural richness of the society. Museums, acting like bridges, connect generations to each other, bring children and families together, and develop skills while entertaining people. Museums are organizations that reflect rich cultural, scientific, environmental, and historical backgrounds. Furthermore, museums function as learning centers with teaching practices and programs. Recently, there have been arguments in the literature that museums may function as educational organizations apart from their traditional roles of conserving, improving, and transferring historical, cultural, sociological, and philosophical backgrounds of countries, nations, or civilizations (Abac1 and Kamaraj, 2009; Karadeniz, 2010; Karadeniz and Okvuran, 2014; Milligan and Brayfield, 2004; Silav, 2014; Tenenbauma, Rappolt-Schlichtmann and Zanger, 2004; Zapri, 2007).

An effective use of museums in the teaching-learning process may be one of the most important keys to the acquisition of meaningful learning in all subject areas. Museums not 
only allow students to see past lives within their own lives but also contribute to their cognitive, physical, emotional, and social development. Children encounter objects and activities they normally do not come across in their daily lives, which has a positive effect on their cognitive development in particular (Oruç and Altın, 2008; Doğan, 2010; Baykan, 2007). According to Çakır İlhan (2007), museums must be taken as institutions which cannot be ignored in pre-school education, and thanks to museums, conceptual education and aesthetic education, which are abstract in essence, can be provided to pre-school children more easily through the possibility of attributing a lot of meanings to the objects in these spaces. Pre-school children learn by discovery through life experiences. As children in this age group are curious and full of desire to learn and discover, they have an open memory and an intrinsic creative thought. Museums, which offer different environments that can provide children with life experiences, can be regarded as ideal educational environments for pre-school education (Abac1, 2003).

A lot of studies emphasize the positive influence of museums on the development of children. The research findings of Abac1 and Kamaraj (2009) found that the museum training programme designed by use of different educational methods contributed to the cognitive development of children. In the conceptual research dealing with children's museums and the need for such museums in Turkey, Karadeniz (2010) highlighted that museums to be established as educational institutions are important for children to socialize, research, and learn. In the conceptual research about children's museums, Silav (2014) concluded that these museums play an important role in providing the society with responsible and successful individuals. Önder, Abac1, and Kamaraj (2009) state that currently, museums are not only places where historical, cultural, and social objects are exhibited but also learning institutions that provide education based on the training programmes which they develop in cooperation with schools. The museums prepared for children are considered valuable as they provide children with experience in a valuable space and allow the teaching activities based on play by increasing interaction between parents and teachers (Henderson and Atencio, 2007). Anderson, Piscitelli, Weier, Everett, and Tayler (2002) observed children based on their experiences in the museum training programme lasting ten weeks and concluded that museum education and children's confrontation with pictures in museums are more effective than showing children pictures about museums and are better for children to get to know their culture.

The findings obtained from empirical and conceptual research on museum education suggest that museums may function, besides their traditional roles, as a learning center and add a new dimension to their social service in this way. Considering the inadequacy of research on museum education involving pre-school children and the need for research in this matter, the present study aims to determine the views of parents about museums and the effects of the activities conducted in museums on the museum perceptions of children. 


\section{Method}

\subsection{Research Model}

Quantitative and qualitative research methods were used together in this study (Creswell, 2014). Questions requiring short answers were asked to the parents of the children participating in the study to obtain their views about museums. Interview technique was used to obtain data about the pictures drawn by the children.

\subsection{Study Group}

The study group consists of 20 children at the age of 5 to 6 attending pre-school education institutions in Karabük province in the 2014-2015 academic period and their parents. Maximum variations sampling, which is a qualitative purposeful sampling method, was employed. The purpose of maximum variation sampling is to create a relatively small study group and reflect the variation of the individuals from this study group who can be a party to the problem under examination at maximum (Yıldırım and Şimşek, 2005). As to the demographic characteristics of the parents, twelve of the parents $(60 \%)$ were female and eight (40\%) were male; half $(n=10)$ were in the 31-35 age range, two in the 26-30 age range, seven in the 36-40 age range, and one was 41 or older; majority held a bachelor's degree $(n=$ 8 ) or a postgraduate degree $(n=9)$, two a high school degree, and one an associate degree; and majority $(n=13)$ had 1 child, six 2 , and one 3 .

\subsection{Instrumentation}

The related literature was reviewed in the first stage of preparing the question form. The researchers created open-ended questions to determine the museum perceptions of the parents and reveal whether the children had had any museum experience before. The question form created searched the previous experiences of the children and the views of the parents about museums. One of the items in the question form was as follows: "Do you think museum tour with children is important? Why?" The questions were sent to three domain experts to ensure the internal validity of the question form. The experts were asked to evaluate the questions in terms of compliance with the research purpose, clarity, and understandability. Based on the expert opinions, the questions were revised and finalized. The researchers conducted a pilot study with one mother and one teacher to determine whether the questions were clear and understandable and whether the answers given to the questions involved intended or expected answers. Another expert was requested to examine the post-interview transcriptions and check whether the questions were clear and understandable and covered the relevant subject as well as its possibility of providing required information. In this way, the validity of the question items was ensured.

\subsection{Data Collection}

Research data were obtained by administering the question form to the mothers between the $1^{\text {st }}$ and the $15^{\text {th }}$ of December 2015. Necessary permissions were obtained to administer the question forms. The question forms were distributed to voluntary mothers. They were requested to return the forms within one week. After the question forms were returned, the information in the data was coded systematically. Here, the main purpose was to reach the 
concepts and relationships that could explain the collected data. To this end, basically similar data were brought together within the framework of certain concepts and themes. Then the mothers' answers were examined and tabulated. This information was confirmed by the mothers' statements that were selected for representative purposes.

\subsection{Data Analysis}

The data obtained from the parents were analyzed through SPSS 16. All of the obtained data were evaluated by each researcher individually. The answers of the parents about museums were grouped and analyzed based on frequency values. The pictures drawn by the children before and after education and the narrations about these pictures were collected through interviews. Then the narrations about the pictures drawn by the children were analyzed.

\subsection{Process}

Safranbolu City Museum, which is located within the Government Office of Safranbolu district of Karabük province, was chosen as the study museum. Built on the hill called "castle" between 1904 and 1906, the Government Office was used as a government office until the $19^{\text {th }}$ of January 1976 and turned out to be unusable as a result of the fire breaking out at that time. In 2000, restoration works were launched by the Ministry of Culture. These works were completed in 2006. Then it was put into service as City History Museum. City History Museum was founded to hold all kinds of information, documentation, objects, visual materials, sound records, and video records about Safranbolu and organize temporary and permanent exhibitions based on this data in order to introduce and demonstrate the cultural, historical, and social richness of the city.

The museum is composed of three floors: ground floor, the $1^{\text {st }}$ floor, and the $2^{\text {nd }}$ floor. The first floor includes a short history of Safranbolu and the building, maps, cultural publications, satellite images, an exhibition hall, and a conference hall. Clothes from the Republic period are exhibited in the hall at the entrance of the second floor. Photos are exhibited in Safranbolu Hall. Information about the history of Safranbolu from the Ottoman period to the Republic period is presented through visual details. Coins and other materials from the Roman period, the Byzantine period, the Ottoman period, and the Republic period are also exhibited. The objects used in the traditional Safranbolu life are exhibited in the Ethnography Hall. The ground floor includes information accompanied by photos about the commercial life and traditional handicrafts in Safranbolu. In addition, the working environments of important craftsmen and tradesmen of Safranbolu such as Şifa Eczanesi (Şifa Pharmacy), Lokumcu (Turkish Delight Maker \& Seller), Yemenici (Kerchief Maker \& Seller), Kunduracı (Shoe Maker \& Seller), Sayacı (Shoe-Upper Maker \& Seller), Semerci (Saddle Maker \& Seller), Saraç (Harness Maker \& Seller), Ahşap iş̧̧iliği (Wooden Labor), Demirci (Blacksmith), Bakırcı (Coppersmith), Kalaycı (Tinsmith), and Esnaf kahvesi (Craftsmen and Tradesmen's Coffeehouse) within Esnaf ve Zanaatkarlar Çarşısı (Tradesmen and Craftsmen's Bazaar) are presented to visitors through unique demonstration technique. The ground floor was deemed appropriate for the study by considering the ages and development characteristics of the children and in the belief that it would be more enjoyable and understandable. 
Preliminary information about the study was given to the parents of the children included in the study and "The Interview Form for Determining the Views of Parents about Museums" was administered to them one day before the activity. After the children arrived in the classroom, a paper and crayons were distributed to them. They were told to draw what comes into their mind when "museum" is mentioned. The narrations of the children about their drawings were noted down in another paper. In the experimental part of the study, before the children arrived, the photos of the museum to be visited that had been taken before were hidden in difference places of the classroom. An opportunity was given to the children for them to find and examine the hidden museum photos accompanied by music by telling them, "Hey children! Do you see any difference in our classroom? You are little explorers and have to find the photos hidden in the classroom". The children were requested to express their opinions about where the photos in their hands could belong. The children were directed to the correct answer through clues. After the correct answer was received, their imperfect knowledge was eliminated by checking their prior knowledge about museums through questions such as "What is a museum?" and "Has anybody gone to a museum before?" Then the question, "In just a moment, we'll go to a museum together. When we go to a museum, we will have to obey certain rules. How do you think we have to behave in the museum?" was asked to the children. They were given an opportunity to answer it. After the answers were received, the museum entrance tickets prepared for them in advance were distributed to the children. Then the children went to the museum. A talk had been made with the museum officer beforehand. He had been requested to tell the children to line up and get the ticket from the child whose turn it was. Accordingly, when the children arrived, the museum officer collected the tickets from the children in turn. After a short tour was taken with the children, they were told that they would take another tour, but that time they had to be more careful. The educator made the following statement: "Little explorers! I'm telling you your new mission. Everybody will find the object which they have in their hand and stand like a sculpture in a way similar to the object and will not break up until I come and touch". For the children to leave the objects they found, they were touched, and the sculptures broke up. The children were told, "Now that the sculptures have broken up, we can talk about the activity we've done", and then it was ensured that they sat in a circle. The children's answers were received in response to the questions asking what they thought about the object as whose sculpture they had just stood, the name of the object, to whom it could belong, by whom it had been used before, and what was the name of the place in which the object was available. The children were allowed to express their feelings, opinions, and recommendations about the activity they had engaged in. Afterwards, the museum officer was asked to give information about the objects in the museum by using examples which the children could understand. Finally, after the children had returned to school and made an evaluation about the tour, they were asked to draw what comes into their mind when "museum" is mentioned. The narrations of the children about the pictures they drew were noted down in another paper. 


\section{Findings}

The parents were asked how they would describe a museum. The answers are presented in Table 1.

Table 1. The museum descriptions of the parents

\begin{tabular}{lc}
\hline Answers & Frequency \\
\hline A place where old works are kept. & 1 \\
$\begin{array}{l}\text { A place where people get information about old } \\
\text { cultures, histories, and lives. }\end{array}$ & 7 \\
$\begin{array}{l}\text { A place that involves material and spiritual cultural } \\
\text { elements. }\end{array}$ & 3 \\
All of them & 9 \\
\hline
\end{tabular}

According to the Table 1 , a considerable number of the participants $(n=7)$ described a museum as a place where people get information about old cultures, histories, and lives. Apart from that, almost half of the participants $(n=9)$ described a museum as a place where old works are kept; where people get information about old cultures, histories, and lives; and which involves material and spiritual cultural elements.

The parents were asked whether they had been to a museum before. 13 of the parents $(65 \%)$ said that they had been to a museum before while 7 parents $(35 \%)$ said that they had never been to a museum before. Upon these answers, 13 participants who had been to at least one museum before were asked what type of a museum they had visited. The obtained findings are presented in Table 2.

Table 2. The museums visited by the parents by type $(\mathrm{n}=13)$

\begin{tabular}{lc}
\hline Type of Museum & Frequency \\
\hline History Museum & 10 \\
Military Museum & 9 \\
Outdoor Museum & 4 \\
Private Museum & 4 \\
Science Museum & 3 \\
Archeology Museum & 3 \\
Ethnography Museum & 2 \\
Children's Museum & 1 \\
\hline
\end{tabular}

As can be seen from Table 2, majority of the participants had been to a history museum $(n=10)$ and a military museum $(n=9)$ before. These two types of museum were the most visited ones. They were followed by outdoor museum $(n=4)$ and private museum $(n=4)$. Children's museum was found to be the least visited museum by the participants.

The parents were asked to express their opinions about the benefits of the involvement of their children in a museum tour. The obtained findings are presented in Table 3. 
Table 3. The distribution of the parents' opinions about the benefits of the involvement of their children in a museum tour

\begin{tabular}{lc}
\hline Benefit & Frequency \\
\hline Learning the historical and cultural past & 12 \\
Promoting learning and providing effective learning & 6 \\
Contribution to the educational process & 1 \\
Enriching the imagination of children & 1 \\
\hline
\end{tabular}

According to the Table 3, all the parents stated that going to the museum would be beneficial for the children. The parents mostly stated that taking the museum tour would be beneficial in terms of learning the historical and cultural past $(n=12)$. Some parents' answers were as follows: "Yes, it's important. I want children to see these places and be informed of history and different cultures." (A20); "Yes, it's for children to have information about old and new cultures and lives" (A18); and "Yes because I think museums provide us with a great deal of information about the past of humanity and instill us historical science" (A4). While 6 participants stated that museum tour would be beneficial by promoting learning and providing effective learning, only 1 parent considered museums beneficial in terms of enriching the imagination of children.

In this study, the authors also asked children to draw what comes into their mind when "museum" is mentioned. The narrations of the children about the pictures they drew were noted down in another paper. Therefore, the authors tried to determine the difference between the perceptions of children on museum after a visit to the museum. Below are two best examples for the difference in children's perception on what museum is.

Table 4. Samples from the pictures drawn by the children before and after the activity in the museum

Question: Draw a museum picture on the paper given.

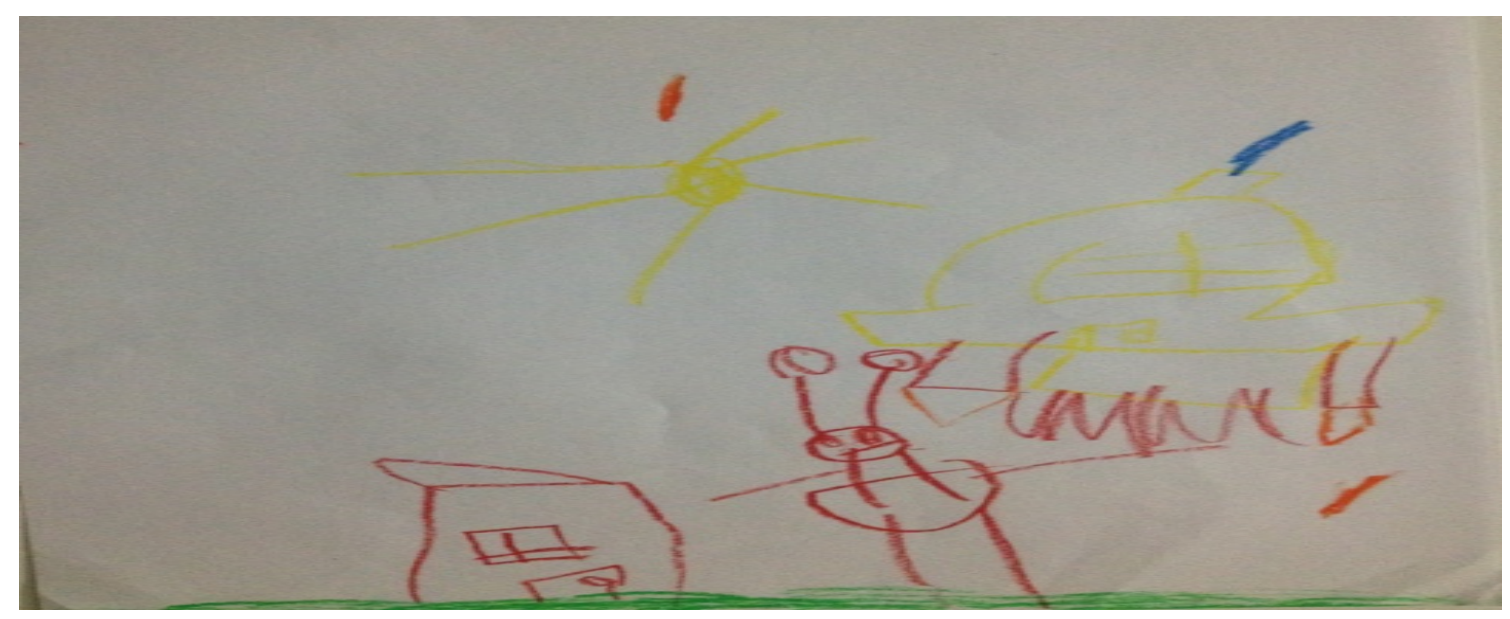

Sample A1 (Before the Activity) 


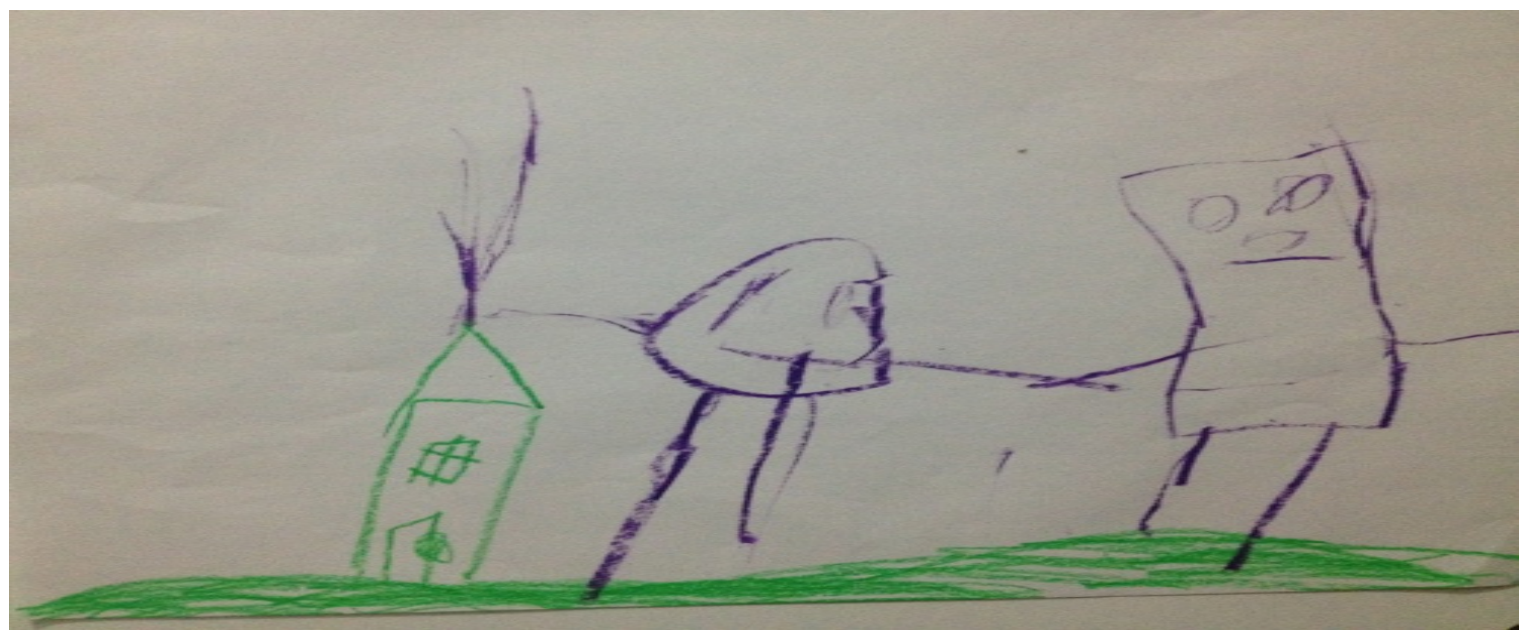

Sample A2 (After the Activity)

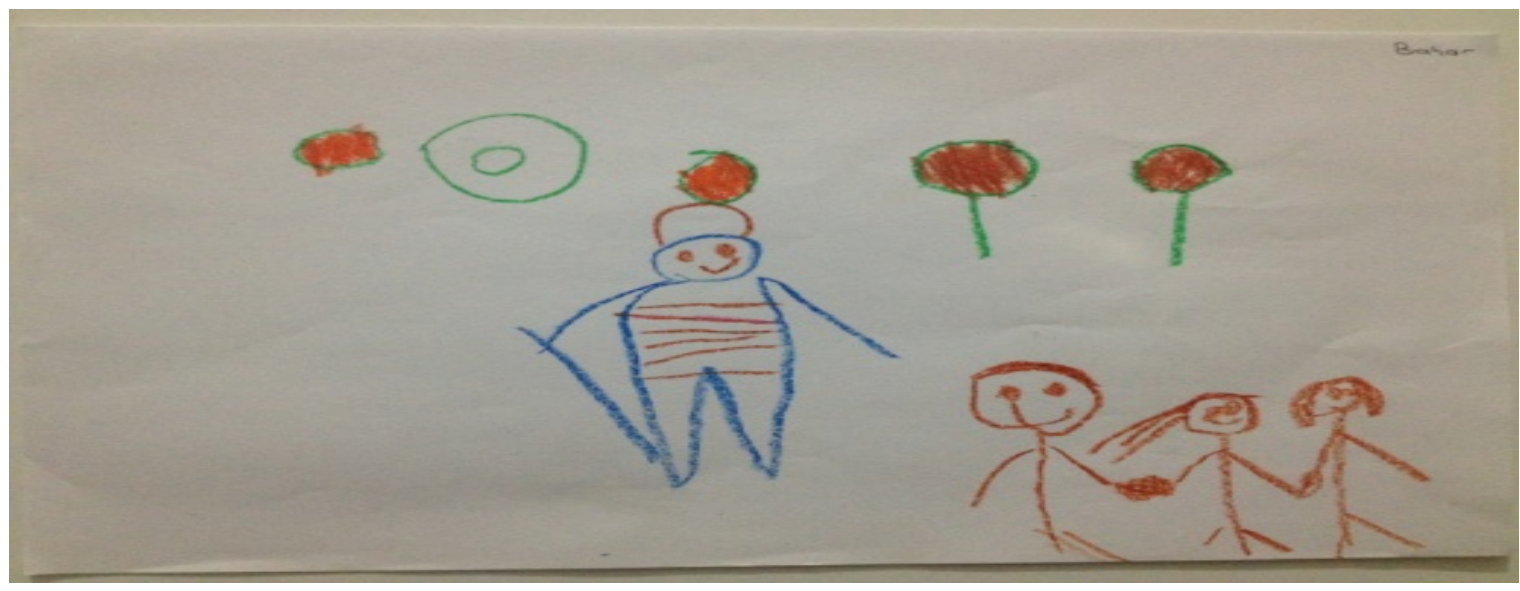

Sample B1 (Before the Activity)

Sample B2 (After the Activity) 


\section{Narration:}

Sample A1 (Before the Activity): I drew a sunny museum.

Sample A2 (After the Activity): There's a man. He's a museum officer. He's standing at the door. I also drew the old room in the museum.

Sample B1 (Before the Activity): There are devices giving out sound records as well as propellers, sculptures, and my family. We're taking a museum tour together.

Sample B2 (After the Activity): I drew the container of swords and became very happy.

\section{Discussion and Conclusion}

This study aimed to determine the views of parents about museums and the effect of the activity in a museum on children's views of museums. To this end, the questionnaire developed by the researchers and supported by expert opinions was administered to the parents. The children, on the other hand, were subjected to pretest and posttest by drawing pictures before and after the museum activity. In response to the question aimed at determining how the parents would describe a museum that was included in the questionnaire prepared for this research, a considerable number of the participants described a museum as a place where people get information about old cultures, histories, and lives. Almost half of the participants described a museum as a place where old works are kept; where people get information about old cultures, histories, and lives; and which involves material and spiritual cultural elements. It is interesting that none of the participants defined a museum as a place where children can entertain or learn. However, it has been argued in the related literature recently that museums also have a very important function as environments where children learn by entertaining. According to Munley and MEM \& Associates (2012), students directly confront with the objects and materials of real life and thus gain experience at first hand during a museum tour or an educational activity organized in a museum, and pre-school children establish personal connections with what they see in a museum. Moreover, when children see an object or undergo an experience that is interesting to them during a museum experience, learning takes place there. The prior knowledge, experiences, and personality characteristics of children are influential on the determination of which object or experience is close to them. Learning process starts when children get in contact with an idea, an object, or an experience in the museum. The first contact of a child with any object in the museum is like the first spark of the learning process. Learning and thinking cover a longer period, and the teaching activities carried out in the museum support this process (Piscitelli, Everett and Weiver, 2003).

When the participants were asked whether they had been to a museum before, 13 participants stated that they had been to a museum with their children before while 7 participants stated that they had not been to a museum with their children before. It is an interesting finding that some parents said that they had not been to any museum with their children before though they lived in a museum city like Safranbolu. However, museums must be taken as institutions which cannot be ignored in pre-school education because thanks to museums, conceptual 
education and aesthetic education, which are abstract in essence, can be provided to pre-school children more easily through the possibility of attributing a lot of meanings to the objects in these spaces (Çakır İlhan, 2007). Before all, museums are not only social service institutions that offer lifelong learning opportunity to the members of the society they are in and contribute to the cultural richness of the society but also amusement and skill development centers that connect generations to each other and bring children and their parents together (IMLS, 2013).

In response to the question asked to determine the types of museum which the parents had visited with their children, a considerable number of the participants stated that they had visited military and history museums. However, only 1 parent stated children's museum in response to this question. However, it is reported in the related literature that children's museums, as distinct from other museums, are places where parents can spend time and learn with their children (ACM, 2009). Children's museums meet the need of educators for a quality leisure time space where they can take their students periodically and the need of parents for spaces where they can spend fun time and acquire knowledge with their children (ACM, 2014). It is emphasized that children's museums provide children with different learning experiences, offer them an opportunity for learning at first hand, and contribute to their physical and emotional development as a whole by affecting different senses (Adigüzel, 2000). From this perspective, it can be thought that the use of children's museums for educational purposes can be an important factor to enhance the quality of education provided to pre-school children in particular. On the other hand, the research finding that children's museums are visited less in comparison to other museums may be an indicator of poor awareness of the parents regarding this matter. However, the limitedness of the number of children's museums in Turkey $(n=4)$ and the existence of these museums in metropolises such as Istanbul $(n=1)$, Ankara $(n=2)$, and Gaziantep $(n=1)$ seem to explain this finding.

The parents were asked to express their opinions about the benefits of the involvement of their children in a museum tour. Based on the answers given by the parents, it can be said that they mostly found museum tours beneficial for learning the historical and cultural past. Only 1 parent opined that museum tours may be beneficial in terms of enriching the imagination of children. It is suggested in the literature that children encounter objects and activities they normally do not come across in their daily lives, which has a positive effect on their cognitive development in particular (Baykan, 2007). As the skills of imagination and creativity require thinking and focusing, it is likely for children to acquire these skills as they develop cognitively.

When the pictures about museum drawn by the children before and after the activity in the museum were examined, it was seen that they mostly drew things based on their prior experiences and imaginations before the activity, but they drew those objects which they saw personally and had a chance to examine in detail during the museum visit after the activity in the museum. Accordingly, it is possible to say that the children did not have any clear idea about museums before the activity and regarded a museum as a space only containing sculptures. On the other hand, it can be said that the children who had never been to a museum before or had only been to one museum with their parents within the scope of a 
pleasure trip developed a positive attitude towards museums and were able to comprehend museums concretely thanks to the activity in the museum and that using museums as environments of learning by entertaining may provide an opportunity for children to acquire a different perspective.

As the children used their cognitive skills such as visual perception, comparison, matching objects, and distinguishing the different one during the activity, it is safe to say that education in museum allows children to learn by entertaining. It can be said that education in museum enables children to learn social behaviors such as communicating with others, lining up, waiting for one's turn, asking questions, making a request, and thanking, and narrating about objects may contribute to the language development of children.

The study concludes that museums are mostly used as a means of acquiring historical and cultural knowledge, and museum tours are considered important for understanding history and culture and knowing the past. The parents participating in the study have mostly been to history and military museums with their children. A considerable number of the participants describe a museum as a place where people get information about old cultures, histories, and lives. Almost half of the participants regard a museum as a place where old works are kept; where people get information about old cultures, histories, and lives; and which involves material and spiritual cultural elements. Accordingly, it is possible to say that most parents do not have adequate knowledge of museums and do not think that museums can be used as educational environments. What is more, significant differences were detected between the museum pictures drawn by the children before and after the activity, and the children found the use of museums as educational environments interesting. All in all, museums facilitate teaching by serving as educational environments. Based on these results;

- Implementation of a training programme for parents involving museum tours in which different functions of museums are explained may be beneficial for improving the awareness of parents in this matter.

- Museums may be used for teaching different concepts to children within the framework of a training programme.

- Activities involving art, play, drama, and music may be included in education in museum as creative practices to improve the creativity and imagination of children.

- In-service training programmes may be developed to inform teachers of how to use museums as educational environments as well as its contributions to teachers, children, and parents.

- Support may be received from relevant departments of universities and protocols may be signed with authorized bodies for preparing the programs of the educational projects that are to be conducted in museums.

- Parental involvement may be ensured by organizing events under the name of "One day in the museum" within the scope of field trips on a monthly basis. In this way, those parents who have never been to a museum before may be provided with museum experience. 
- Museum officers may be informed about the museum activity in advance so that they engage in the activity with children.

\section{References}

Abac1, O., \& Kamaraj, I. (2009). Museums as an educational medium: An implementation model. Procedia Social and Behavioral Sciences, 1, 1337-1341. http://dx.doi.org/10.1016/J.SBSPRO.2009.01.235

Abacı, O. (2003). Müze ve eğitim: Eğitim ortamı olarak müzeler [Museum and education: Museums as educational environment]. İstanbul: Y1ldız Teknik University.

Adıgüzel, H. Ö. (2000). Eğitim bilimlerinde (Güzel sanatlar eğitiminde) bir uzmanlık alanı olarak kültür pedagojisi [Cultural pedagogy as a study (Expertation) field in educational science (In arts education)]. (Unpublished doctoral dissertation). Ankara University, Ankara, Turkey.

Anderson, D., Piscitelli, B., Weier, K., Everett, M., \& Tayler, C. (2002). Children's museum experiences: Identifying powerful mediators of learning. Curator, 45, 213-231. http://dx.doi.org/10.1111/J.2151-6952.2002.TB00057.

Ankara Çocuk Müzesi (AÇM) (2014). Öğretmen kitabı. Çocuk müzeleri [Teacher book: Child museums]. October 26, 2014 from http://ankaracocukmuzesi.com/Ogretmen Kitabiweb.pdf.

Associations of Children's Museums (ACM) (2004). What is a children's museum? October 25, 2014 from www.childrensmuseums.org.

Başal, H. A. (2005). Okulöncesi eğitiminin ilke ve yöntemleri [The principles and methods of preschool education]. İstanbul: Morpa.

Baykan, Z. Ö. (2007). 2005 ve 2006 İlköğretim programlarının “Müze Eğitimi” açısından değerlendirilmesi [Evaluation of museum education of primary education programs developed in 2005 and 2006] (Unpublished master thesis). Ankara University, Ankara, Turkey

Creswell, J. W. (2014). Araştırma deseni nitel, nicel ve karma yöntem yaklaşımları [Research design qualitative, quantitative, and mixed methods approaches]. (1. Ed.) (Translation: S. B. Demir) Ankara: Eğiten Kitap.

Çakır İlhan, A. (2007). Sanat eğitimi, müze eğitimi ve yaratici drama üzerine [The education of art, museum and on creative drama]. Retrieved December 19, 2014 from http://www.okulonceciyiz.biz/soylesiler/47-prof-dr-aysecakir-ilhan-ile-sanat-egitimi-muz e-egitimi-ve-yaratici drama-uzerine.html

Doğan, Y. (2010). Primary school students' benefiting from museums educational purposes. International Journal of Social Inquiry, 3(2), 137-164.

Heckman J. J. (2004). Invest in the very young. Retrieved on December 19, 2014 from Montreal,Quebec. http://www.childencyclopedia.com/documents/HeckmanANGxp.pdf 
Henderson, T., \& Atencio, D. (2007). Integration of play, learning, and experience: What museums afford young visitors. Early Childhood Education Journal, 35, 245-251.

Institute of Museum and Library Services (IMLS) (2013). Growing young minds. How Museums and Libraries Create Lifelong Learners. Retrieved on October 25, 2014 from http://www.imls.gov/assets/1/AssetManager/Growing YoungMinds.pdf

International Council of Museums (ICOM) (2014). Museum definition. Retrieved October 25, 2014 from http://icom.museum/the-vision/museum-definition/

Karadeniz, C. (2010). Children's museums and necessity for children's museums in Turkey. Procedia Social and Behavioral Sciences, 2, 600-608.

Karadeniz, C. ve Okvuran, A. (2014). Müzede bir gece: Ankara Üniversitesi öğrencileri ile Çorum Arkeoloji Müzesi'nde müze eğitimi [A night at the museum: Museum education with Ankara University students at Çorum Museum of archeology]. Illkögretim Online, 13(3), 865-879.

Mercin, L. (2006). Resim dersini müze kaynaklı oluşturmacı öğrenme yaklaşımı etkinliklerine göre uygulamanın erişiye, kalıcılığa ve tutuma etkisi? (Diyarbakır ili örneği) [The effect of conducting the painting lessons according to museum-based constructivist learning theory activities on achievement, retention and attitude? (The sample of Diyarbakir province] (Unpublished master thesis). Gazi University, Ankara, Turkey.

Milligan, M. J., \& Brayfield, A. (2004). Museums and childhood. Negotiating organizational lessons. Childhood, 11(3), 275-301.

Munley, M. E., \& MEM \& Associates. (2012). Early learning in museums. A review of literature. Retrieved October 20, 2014 from http://www.si.edu/Content/SEEC/docs/ mem\%20literature\%20review\%20early\%20learning\%20in\%20museums\%20final $\% 204$ $\% 2012 \% 202012$.pdf

Oruç, A. G. S. ve Altın, B. N. (2008). Müze eğitimi ve yaratıcı drama [Museum education and creative drama]. Çukurova Üniversitesi Ĕ̈itim Fakültesi Dergsisi, 3, 125-141.

Önder, A., Abacı, O. ve Kamaraj, I. (2009). "Müzelerin eğitim amaçlı kullanımı projesi”: İstanbul Arkeoloji Müzesi'ndeki Marmara örneklemi [The project of "employing the museums for educational goals": Example of Marmara]. Pamukkale Üniversitesi Ĕ̈itim Fakültesi Dergisi, 25, 103-117.

Piscitelli, B., Everett, M., \& Weiver, K. (2003). Enhancing young children's museum experiences. A manual for museum staff. Retrieved September 25, 2014, from https:/hollandmvp.files.wordpress.com/2014/07/enhancing-young-childrens-museum-ex periences.pdf

San-Bayhan, P. ve Artan, İ. (2004). Çocuk gelişimi ve eğitimi [Child development and education]. İstanbul: Morpa Kültür Yayınları.

Senemoğlu, N. (2007). Gelişim öğrenme ve öğretim. Kuramdan uygulamaya [Development, learning and teaching. From theory to practice]. Ankara: Gönül Yayıncılık. 


\section{Macrothink}

International Journal of Education

ISSN 1948-5476 2016, Vol. 8, No. 1

Silav, M. (2014). Museums for children. Procedia Social and Behavioral Sciences, 122, $357-361$.

Tenenbauma, H. R., Rappolt-Schlichtmann, G., \& Zanger, V. V. (2004). Children's learning about water in a museum and in the classroom. Early Childhood Research Quarterly, 19, 40-58.

Türk Dil Kurumu (TDK) (2014).Güncel Türkçe sözlük. Retrieved December 25, 2014 fromhttp://www.tdk.gov.tr/index.php?option=com_gts\&arama=gts\&guid=TDK.GTS.54 4b9ae1e380e7.23816508.

Yıldırım, A. ve Şimşek, H. (2005). Sosyal bilimlerde nitel araştırma yöntemleri [Qualitative research methods in social sciences]. Ankara: Seçkin Yayıncılık.

Zapri, D. (2007). An ecological examination of young children's museum-related perceptions: A Greek case study (Doctoral dissertation). Retrieved from ProQuest Dissertations and Thesis database (UMI: 301700748).

\section{Copyright Disclaimer}

Copyright for this article is retained by the author(s), with first publication rights granted to the journal.

This is an open-access article distributed under the terms and conditions of the Creative Commons Attribution license (http://creativecommons.org/licenses/by/3.0/). 